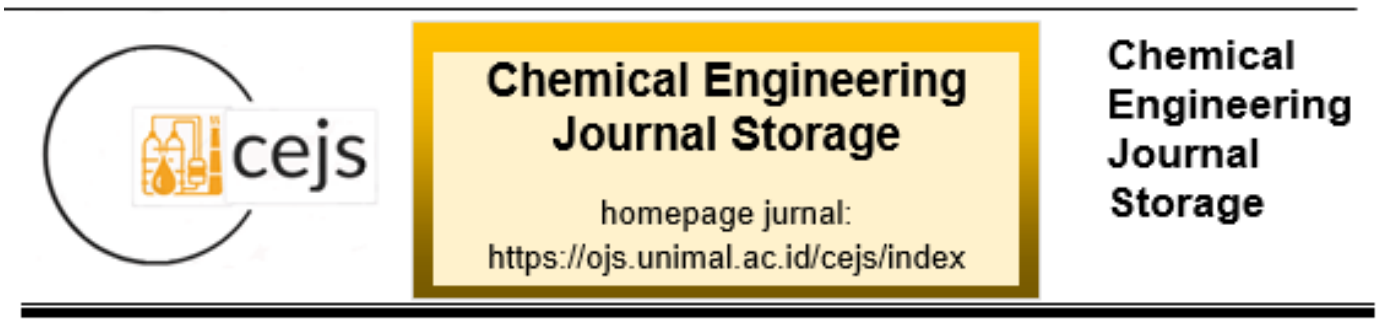

\title{
PEMBUATAN AIR MINUM ALKALI MENGGUNAKAN METODE ELEKTROLISIS
}

\author{
Lamkaruna Rizki, Lukman Hakim*, Zulnazri \\ Jurusan Teknik Kimia, Fakultas Teknik, Universitas Malikussaleh \\ Kampus Utama Cot Teungku Nie Reuleut, Muara Batu, Aceh Utara - 24355 \\ Korespondensi:HP: 085296148295, e-mail: lukman.hakim@unimal.ac.id
}

\begin{abstract}
Abstrak
Air alkali adalah air yang bersifat basa atau mempunyai $p H$ di atas 7. Tujuan penelitian ini adalah mengidentifikasi variable-variabel yang mempengaruhi proses pembuatan air minum alkali, merancang alat proses pembuatan air minum alkali dan mengetahui perbandingan kualitas air minum alkali dan air biasa. Air yang telah diuji kadar TDS dan pH dimasukkan kedalam wadah elektrolisis, kemudian dielektrolisis dengan variasi tegangan 5 volt, 10 volt, 15 volt, 20 volt, dan 25 volt menggunakan variasi waktu 1 jam, 2 jam, 3 jam, 4 jam, dan 5 jam. Kemudian air hasil elektrolisis dilakukan uji organoleptic (bau, warna, dan rasa) dan uji kekeruhan. Dari hasil penelitian diperoleh kenaikan $\mathrm{pH}$ tertinggi yaitu pada tegangan 25 volt selama 5 jam dengan $p H$ sebesar 8,3. Kemudian berdasarkan uji organoleptic yang dilakukan pada 8 orang orang responden diperoleh hasil bahwa air alkali hasil elektrolisis memenuhi syarat kelayakan air minum yaitu tidak memiliki bau, warna, dan rasa. Dari penelitian ini dapat diketahui bahwa kenaikan pH pada proses elektrolisis dipengaruhi oleh besar tegangan dan lama waktu elektrolisis, kenaikan $\mathrm{pH}$ tertinggi terdapat pada sampel hasil elektrolisis dengan tegangan 25 volt selama 5 jam yaitu $\mathrm{pH}$ sebesar 8,3 .
\end{abstract}

Kata kunci: Air Alkali, Elektrolisis, Uji Organoleptik, Kenaikan pH, Tegangan, dan Waktu.

\section{Pendahuluan}

Air merupakan sumber daya alam yang diperlukan untuk hajat hidup orang banyak, bahkan semua makhluk hidup. Air menjadi kebutuhan primer yang diperlukan untuk kebutuhan sehari-hari seperti minum, masak, mandi sampai kebutuhan pengolahan industri. Oleh sebab itu, air mutlak ada agar kehidupan dapat terus berlangsung. Sekitar $70-80 \%$ berat badan manusia terdiri atas air. 
Dalam hal persyaratan kualitas,air minum harus sesuai dengan ketentuan yang tertuang dalam Peraturan Menteri Kesehatan Republik Indonesia No. 492/MENKES/PER/IV/2010 dimana ada dua parameter yaitu parameter wajib dan parameter tambahan yang meliputi persyaratan kimia, mikrobiologi, fisik dan radio aktivitas. Air minum telah ditetapkan dari Badan Pengawasan Obat dan Makanan (BPOM) yang tentunya sudah menerapkan Standar Nasional Indonesia (SNI 01-35532006) dalam pengelolaan air minum agar tidak terkontaminasi zat ataupun bahan yang membahayakan kesehatan tubuh, salah satunya adalah logam berat yang bersifat esensial. Salah satu misalnya mangan yang memiliki standar baku mutu sebesar 0,4mg/L (Khaira, 2014)

Saat ini air minum dalam kemasan (AMDK) masih mendominasi pangsa pasar di Indonesia. Salah satu jenis air minum dalam kemasan sedang berkembang saat ini adalah air alkali. Menurut asosiasi perusahaan air minum dalam kemasan Indonesia (ASPADIN) air alkali dengan persentase 15 miliarperliter pertahun atau setara dengan 65.000.000 kemasan/bulan. Meningkatnya kesadaran dan kepedulian masyarakat terhadap air minum yang layak di tengah-tengah minimnya sumber air minum yang hiegenis, mendorong masyarakat, baik individu, rumah tangga, perkantoran, dan industri beramai-ramai beralih ke air alkali.

Air alkali adalah air yang bersifat basa atau mempunyai $\mathrm{pH}$ di atas 7. Air alkali memiliki kandungan yang bermanfaat bagi tubuh, seperti kaya akan mineral dan ion hidrogenaktif. Ion hidrogenaktif ini menghasilkan antioksidan alami yang dapat membangkitkan energi, dan melindungi sel-sel tubuh secara optimal dariancaman radikal bebas (Warsyidah et al., 2019)

Air alkali terionisasi dapat menghilangkan oksigen aktif dan melindungi DNA dari kerusakan oksidatif. Oksigen aktif atau radikal bebas yang dianggap menyebabkan kerusakan oksidatif yang luas untuk makromolekul biologis, yang membawa berbagai penyakit serta penuaan. Senyawa ideal untuk menghilangkan oksigen aktif adalah 'hidrogen aktif'. 'Hidrogen aktif' dapat diproduksi dekat katoda selama elektrolisis air. AAT yang dihasilkan $\mathrm{pH}$ tinggi, rendah oksigen 
terlarut (DO), sangat tinggi molekul hydrogen terlarut dan nilai potensi redoks sangat negatif (ORP). Ini melindungi dan mencegah kerusakan oksidatif serta mencegah terjadinya kanker (Sukohar \& Marliando Satria Pangestu Catur, 2016)

Selama proses elektrolisis air berlangsung, air di sisi anoda (kutub positip) akan bersifat asam, sedangkan air di sisi katoda (kutub negatip) akan bersifat basa. Permukaan ketinggian air dalam kedua tabung pada awalnya sama. Selama proses elektrolisis, maka permukaan ketinggian air dalam tabung yang terhubung dengan kutub negatip (basa) akan naik sedangkan dalam tabung yang terhubung dengan kutub positip (asam) permukaan ketinggian airnya akan turun. Proses elektrolisis ditunjukkan pada gambar 1.1.

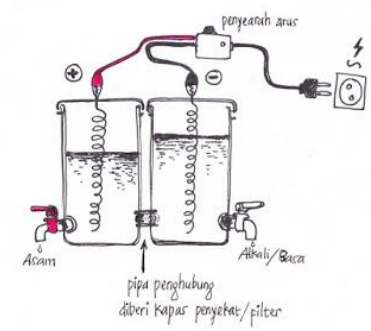

Gambar 1.1 cara kerja elektrolisis

Proses perubahan air minum biasa menjadi air basa dan asam terjadi karena adanya proses kimia sebagai berikut :

$$
\begin{aligned}
& 2 \mathrm{H}_{2} \mathrm{O}+2 \mathrm{e}^{-} \rightarrow \mathrm{H}_{2}+2 \mathrm{OH}^{-} \text {(di katoda) } \\
& 2 \mathrm{H}_{2} \mathrm{O} \rightarrow 4 \mathrm{e}^{-}+\mathrm{O}_{2}+4 \mathrm{H}^{+} \text {(di anoda) }
\end{aligned}
$$

Pada katode, dua molekul air bereaksi dengan menangkap dua elektron, kemudian tereduksi menjadi gas $\mathrm{H}_{2}$ dan ion hidroksida ( $\left.\mathrm{OH}-\right)$. Sementara itu pada anode, dua molekul air lain terurai menjadi gas oksigen $\left(\mathrm{O}_{2}\right)$, melepaskan 4 ion $\mathrm{H}+$ serta mengalirkan elektron ke katode. Hasil pengolahan secara elektrolisis akan menghasilkan 2 macam jenis sifat air yaitu Asam dan Basa.

Air basa atau alkali adalah air dengan pH 7,6 sampai 9,5. Air alkali bila rutin diminum bisa membantu mencegah timbulnya penyakit dalam tubuh manusia. Masyarakat telah menggunakan air basa sebagai terapi beberapa penyakit. Bahkan ada yang menggunakan air basa sebagai terapi untuk 
meningkatkan trombosit darah untuk pasien demam berdarah (Patabang \& Leda, 2018).

\section{Bahan dan Metode}

Bahan baku pada penelitian ini merupakan air reserve osmosis (RO) dan elektroda (stainless steel). Peralatan penelitian yang digunakan dalam penelitian ini adalah beaker glass, TDS meter, AAS, $\mathrm{pH}$ meter, dan power DC.

Penelitian ini terdiri dari dua tahap yaitu persiapan alat elektrolisis (termasuk persiapan bahan baku dan persiapan alat elektrolisis), dan proses elektrolisis. Variabel percobaan dilakukan terhadap waktu dan tegangan.

Persiapan alat elektrolisis dilakukan dengan cara disiapkan dua bejana atau tabung, kemudian bejana atau tabung dipasangkan keran air lalu pasang penghubung diantara dua bejana atau tabung yang telah disediakan, persiapan bahan baku dilakukan dengan cara yaitu mengukur TDS dan $\mathrm{pH}$ seumber air kemudian uji kebersihan air menggunakan water elektrolyzer.

Proses elektolisis dilakukan dengan cara masukkan air reserve osmosis kedalam bejana atau tabung yang telah disiapkan, kemudian hubungkan stailess steel dengan power DC dengan cara kutup positif dihubungkan dengan tanda warna merah pada bejana atau tabung pertama dan kutup negatif dengan terminal kawat stainless pada bejana kedua, kemudian hubungkan rangkaian penyearah (adaptor) ke tegangan 5 volt, 10 volt, 15 volt, dan 20 volt dan tunggu hasil elektrolisis selama 1 jam, 2 jam, 3 jam, 4 jam dan 5 jam (Fauziah et al., 2019).

\section{Hasil dan Diskusi}

\subsection{Pengaruh Tegangan dan Waktu Terhadap Kenaikan pH}

Pada gambar 3.1 pengaruh tegangan dan waktu terhadap kenaikan $\mathrm{pH}$ cenderung meningkat. Hal ini menunjukkan bahwa semakin meningkatnya tegangan dan lama waktu proses elektrolisis mengakibatkan terjadinya kenaikan derajat keasaman $(\mathrm{pH})$, karena semakin banyaknya pembentukan konsentrasi $\mathrm{OH}^{-}$. 


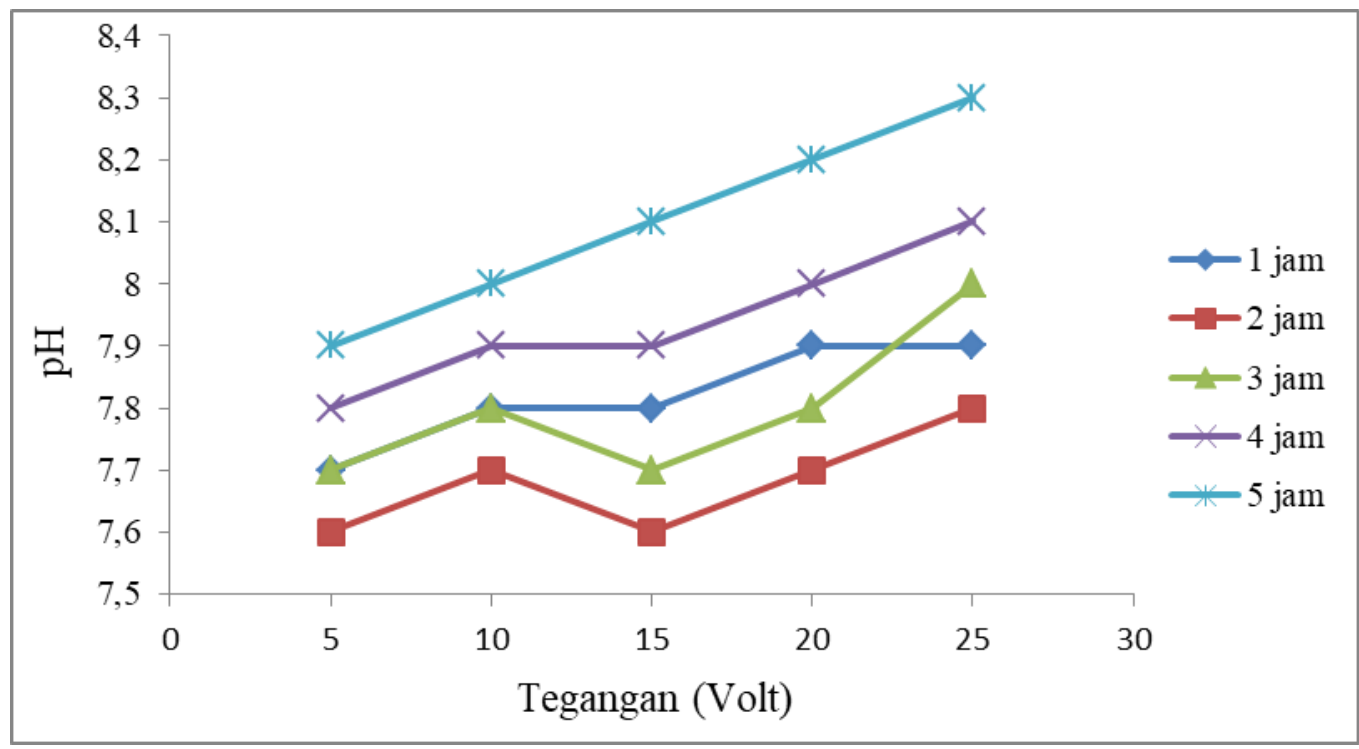

Gambar 3.1 Pengaruh Tegangan dan Waktu Terhadap Kenaikan $\mathrm{pH}$

Pengaruh tegangan terhadap kenaikan $\mathrm{pH}$ cenderung meningkat. Hal ini menunjukkan bahwa semakin meningkatnya tegangan pada proses elektrolisis mengakibatkan terjadinya kenaikan derajat keasaman $(\mathrm{pH})$, karena semakin banyaknya pembentukan konsentrasi $\mathrm{OH}^{-}$, namun pada tegangan 15 volt dan waktu elektrolisis 2 jam dan 3 jam mengalami penurunan dikarenakan pengukuran $\mathrm{pH}$ masih menggunakan kertas indikator $\mathrm{pH}$ universal sehingga pengukuran kurang akurat.

Kenaikan $\mathrm{pH}$ terjadi pada setiap perlakuan sejalan dengan bertambahnya lama waktu elektrolisis. Kenaikan $\mathrm{pH}$ terjadi diakibatkan semakin banyaknya pembentukan konsentrasi $\mathrm{OH}^{-}$, pada waktu elektrolisis selama 5 jam mengalami kenaikan $\mathrm{pH}$ yang diakibatkan karena waktu elektrolisis semakin besar dan semakin banyaknya pembentukan konsentrasi $\mathrm{OH}^{-}$, sedangkan pada waktu elektrolisis selama 2 jam mengalami penurunan $\mathrm{pH}$ yang diakibatkan karena waktu elektrolisis semakin kecil dan semakin kecilnya pembentukan konsentrasi $\mathrm{OH}^{-}$(Patabang, 2018). 


\subsection{Uji Organoleptik Terhadap Bau}

Adapun data hasil uji organoleptik terhadap bau yang dilakukan pada 8 orang responden dapat dilihat pada tabel 3.1 di bawah ini :

Table 3.1 Data Hasil Uji Organoleptik Terhadap Uji Bau

\begin{tabular}{|c|c|c|}
\hline \multirow{2}{*}{ Responden } & \multicolumn{2}{|c|}{ Uji Bau } \\
\cline { 2 - 3 } & Memiliki Bau & Tidak Memiliki Bau \\
\hline 1 & - & $\checkmark$ \\
\hline 2 & - & $\checkmark$ \\
\hline 3 & - & $\checkmark$ \\
\hline 4 & - & $\checkmark$ \\
\hline 5 & - & $\checkmark$ \\
\hline 6 & - & $\checkmark$ \\
\hline 7 & - & $\checkmark$ \\
\hline 8 & - & $\checkmark$ \\
\hline
\end{tabular}

Tabel 3.1 diatas merupakan data uji organoleptic yang dilakukan pada 8 orang responden didapatkan hasil yaitu semua responden menjawab air hasil elektrolisis tidak memiliki bau, sehingga air alkali hasil elektrolisis tersebut memenuhi syarat air minum yang layak dikonsumsi berdasarkan Berdasarkan peraturan Menteri Kesehatan RI No.492/Menkes/Per/VI/2010 meliputi air tidak berbau, kadar warna 15 CTU (tidak berwarna), air tidak berasa, kekeruhan air 5\% dan TDS 500.

\subsection{Uji Organoleptik Terhadap Warna}

Adapun data hasil uji organoleptik terhadap warna yang dilakukan pada 8 orang responden dapat dilihat pada tabel 3.2 dibawah ini :

Table 3.2 Data Hasil Uji Organoleptik Terhadap Uji Warna

\begin{tabular}{|c|c|c|}
\hline \multirow{2}{*}{ Responden } & \multicolumn{2}{|c|}{ Uji Warna } \\
\cline { 2 - 3 } & Memiliki Warna & Tidak Memiliki Warna \\
\hline 1 & - & $\checkmark$ \\
\hline 2 & - & $\checkmark$ \\
\hline 3 & - & $\checkmark$ \\
\hline 4 & - & $\checkmark$ \\
\hline 5 & - & $\checkmark$ \\
\hline 6 & - & $\checkmark$ \\
\hline 7 & - & $\checkmark$ \\
\hline 8 & - & $\checkmark$ \\
\hline
\end{tabular}


Tabel 3.2 diatas merupakan data uji organoleptik yang dilakukan pada 8 orang responden didapatkan hasil yaitu semua responden menjawab air hasil elektrolisis tidak memiliki warna, sehingga air alkali hasil elektrolisis tersebut memenuhi syarat air minum yang layak dikonsumsi berdasarkan Berdasarkan peraturan Menteri Kesehatan RI No.492/Menkes/Per/VI/2010 meliputi air tidak berbau, kadar warna 15 CTU (tidak berwarna), air tidak berasa, kekeruhan air 5\% dan TDS 500.

\subsection{Uji Organoleptik Terhadap Rasa}

Adapun data hasil uji organoleptik terhadap rasa yang dilakukan pada 8 orang responden dapat dilihat pada tabel 3.3 dibawah ini :

Table 3.3 Data Hasil Uji Organoleptik Terhadap Uji Rasa

\begin{tabular}{|c|c|c|}
\hline \multirow{2}{*}{ Responden } & \multicolumn{2}{|c|}{ Uji Rasa } \\
\cline { 2 - 3 } & Memiliki Rasa & Tidak Memiliki Rasa \\
\hline 1 & - & $\checkmark$ \\
\hline 2 & - & $\checkmark$ \\
\hline 3 & - & $\checkmark$ \\
\hline 4 & - & $\checkmark$ \\
\hline 5 & - & $\checkmark$ \\
\hline 6 & - & $\checkmark$ \\
\hline 7 & - & $\checkmark$ \\
\hline 8 & - & $\checkmark$ \\
\hline
\end{tabular}

Tabel 3.3 diatas merupakan data uji organoleptik yang dilakukan pada 8 orang responden didapatkan hasil yaitu semua responden menjawab air hasil elektrolisis tidak memiliki rasa, sehingga air alkali hasil elektrolisis tersebut memenuhi syarat air minum yang layak dikonsumsi berdasarkan Berdasarkan peraturan Menteri Kesehatan RI No.492/Menkes/Per/VI/2010 meliputi air tidak berbau, kadar warna 15 CTU (tidak berwarna), air tidak berasa, kekeruhan air 5\% dan TDS 500.

\subsection{Analisa Uji Kekeruhan Menggunakan alat $U V$ Vis spectrophotometer}

Adapun hasil uji kekeruhan air hasil elektrolisis menggunakan alat $U V$ Vis Spectrophotometer dapat dilihat pada tabel 3.4 dibawah ini : 
Tabel 3.4 Data Hasil Uji Kekeruhan Air

\begin{tabular}{|c|l|l|}
\hline Sampel & \multicolumn{1}{|c|}{ Absorben } & \multicolumn{1}{|c|}{ Kekeruhan (\%) } \\
\hline sampel 20 (pH 8,2) & 0,0012 & 0,1261 \\
\hline Sampel 25 (pH 8,3) & 0,0013 & 0,1387 \\
\hline
\end{tabular}

Hasil dari tabel 3.4 diatas menunjukkan bahwa pada sampel 20 dengan $\mathrm{pH}$ 8,2 tingkat kekeruhan hanya mencapai angka $0,1261 \%$ yang dimana bahwa angka tersebut lebih rendah dari pada sampel 25 dengan $\mathrm{pH} 8,3$ yang tingkat kekeruhannya mencapai angka 0,1387\% yang berarti air pada sampel 20 memiliki nilai kekeruhan yang lebih kecil dibandingkan dengan air pada sampel 25. Hal tersebut menyatakan bahwa tingkat zat pengotor yang terdapat pada sampel 20 dengan $\mathrm{pH} 8,2$ lebih rendah dibandingkan sampel 25 dengan $\mathrm{pH}$ 8,3. Dengan demikian, semakin tinggi kadar zat pengotor maka semakin keruh warna air yang dihasilkan.

\section{Simpulan dan Saran}

Berdasarkan hasil penelitian didapatkan kenaikan $\mathrm{pH}$ air hasil elektrolisis dipengaruhi oleh tegangan dan lama waktu elektrolisis. Air hasil elektrolisis yang memiliki $\mathrm{pH}$ terbaik didapatkan pada sampel 20 dengan $\mathrm{pH} 8,2$ dan pada sampel

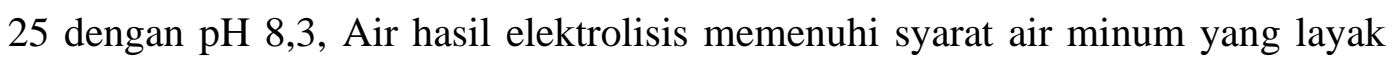
dikonsumsi setelah dilakukan uji organoleptic yaitu tidak memiliki warna, bau, dan rasa, dan berdasarkan hasil uji kekeruhan air didapatkan hasil sampel 20 dengan $\mathrm{pH}$ 8,2 memiliki tingkat kekeruhan yang lebih rendah dibandingkan dengan sampel 25 dengan $\mathrm{pH} 8,3$.

Penelitian pembuatan air minum alkali dapat dikembang lagi dengan menggunkan elektroda yang berbeda dengan variasi tegangan yang lebih tinggi dan waktu elektrolisis yang lebih lama. Untuk lebih mengetahui kelayakan dan kualitas air minum alkali dapat ditambahkan uji kandungan kimia dan uji bakteriologi seperti coliform dan colitinja. 


\section{Daftar Pustaka}

1. Fauziah, A., Elektro, F. T., Telkom, U., Cell, S., \& Alkali, A. (2019). Sistem Catu Daya Penghasil Air Alkali Dengan Modul Solar Cell. EProcceeding of Engineering, 6(1), 165-171.

2. Khaira, K. (2014). Analisis Kadar Tembaga (Cu) Dan Seng (Zn) Dalam Air Minum Isi Ulang Kemasan Galon di Kecamatan Lima Kaum Kabupaten Tanah Datar. Sainstek: Jurnal Sains Dan Teknologi, 6(2), 116-123. http://ecampus.iainbatusangkar.ac.id/ojs/index.php/sainstek/article/view/1 11

3. Patabang, S., \& Leda, J. (2018). Pengolahan air minum alkali berbasis rumah tangga 1). Prosiding Seminar Hasil Pengabdian (SNP2M) 2018 (Pp.150-153) 978-602-60766-5-6, 2018, 150-153. http://jurnal.poliupg.ac.id/index.php/snp2m/article/viewFile/1414/1312

4. Sukohar, A., \& Marliando Satria Pangestu Catur, M. (2016). Air Alkali Terionisasi Pencegahan Termutakhir Timbulnya Kanker Ionized Alkaline Water As The Latest Prevention of Cancer Emergence. 5(April).

5. Warsyidah, A. A., Syarif, J., \& Abdullah, C. (2019). ANALISIS KADAR MANGAN (Mn) PADA AIR ALKALI DENGAN MENGGUNAKAN SPEKTROFOTOMETER SERAPAN ATOM (SSA). Jurnal Media Laboran, 9(1). 